\title{
PERANCANGAN SISTEM INFORMASI PENYALURAN BERAS (RASKIN) PADA DESA BALONGGANDU JATISARI
}

\author{
Yuli Komalasari ${ }^{1}$, Dede Firmansyah ${ }^{2}$, Riska Rachmania Agatha ${ }^{3}$, Diah Wijayanti ${ }^{4}$ \\ ${ }^{1}$ Fakultas Teknologi Informasi Universitas Bina Sarana Informatika, Jl. Kramat Raya No. 98 \\ Senen,Jakarta Pusat 10450 T: (021) 23231170 F: (021)21236158 \\ e-mail: ${ }^{1}$ yuli.yks@bsi.ac.id, \\ ${ }^{2}$ Fakultas Teknologi Informasi Universitas Bina Sarana Informatika, Jl. Kramat Raya No. 98 \\ Senen,Jakarta Pusat 10450 T: (021) 23231170 F: (021)21236158 \\ e-mail: 22dede.dfs@bsi.ac.id \\ ${ }^{3}$ Fakultas Teknologi Informasi Universitas Bina Sarana Informatika, Jl. Kramat Raya No. 98 \\ Senen,Jakarta Pusat 10450 T: (021) 23231170 F: (021)21236158 \\ ${ }^{4}$ Fakultas Teknologi Informasi Universitas Bina Sarana Informatika, Jl. Kramat Raya No. 98 \\ Senen,Jakarta Pusat 10450 T: (021) 23231170 F: (021)21236158 \\ e-mail: ${ }^{4}$ diah.dhw@bsi.ac.id
}

\begin{abstract}
Rice is a staple food that is needed by every human being every day The increasing number of population that occurs in almost all regions of Indonesia poses a threat to staple food supplies. The more people in each region, the food supply at the national and regional levels increases. To meet the rice food supply for the needs of the community and also the stability of the price of rice, the government established a logistical agency called BULOG (Logistics Business Entity) which played an important role in regulating the supply of rice, rice stock, minimum maximum supply, price of rice, etc. .The problem of poverty is one of the fundamental problems that is the center of attention of governments in any country. One of the government programs used to alleviate poverty is Raskin (Rice for poor families) organized by BULOG. In this case the distribution mechanism of poor rice distribution in Kosar Village there are still many processes that have problems such as the data collection of Raskin rice recipients who are still classified as less effective as in conducting RASKIN receiver data collection, it is still conventional. This causes data to be lost or corrupted. As well as processing data using Microsoft Excel, if the device used is damaged, data is lost and there is no data backup, the data processing must be repeated again. the Raskin rice distribution information system is effective and efficient and makes it easy for staff, so they can achieve competitive advantage. The system can be developed and applied to areas that need it so that computerization of existing data occurs. the Raskin rice distribution information system is effective and efficient and makes it easy for staff, so they can achieve competitive advantage. The system can be developed and applied to areas that need it so that computerization of existing data occurs.
\end{abstract}

Keywords : Information System Design, Poverty Problems, Raskin, Rice Distribution (Raskin), Bulog

\section{PENDAHULUAN}

Beras merupakan bahan pangan pokok yang sangat diperlukan setiap manusia dalam setiap harinya. Beras merupakan hasil pengolahan dari padi yang memiliki sumber karbohidrat tertinggi dibandingkan bahan pangan lainnya, beras memiliki 360 kalori dan 78,9 gram hal ini yang menjadikan beras sebagai bahan pokok pangan utama manusia, terutama masyarakat Indonesia. Meningkatnya jumlah penduduk yang terjadi pada hampir seluruh wilayah Indonesia menjadi ancaman terhadap persediaan pangan pokok.

Semakin banyak penduduk yang ada pada setiap wilayah maka persediaan pangan di tingkat nasional dan regional semakin meningkat. Untuk memenuhi persediaan pangan beras demi kebutuhan masyarakat dan juga kestabilan harga beras maka pemerintah membentuk suatu badan logistik yang disebut dengan BULOG (Badan Usaha Logistik) yang berperan 
penting dalam mengatur pemasokan beras, stok beras, persediaan maksimum minimum, harga beras, dan lain-lain.

Kemiskinan merupakan salah satu persoalan mendasar yang menjadi pusat perhatian pemerintah dinegara manapun terutama di negara Indonesia. Salah satu Program Pemerintah untuk menanggulangi kemiskinan adalah Raskin(Beras untuk keluarga miskin) yang diselenggarakan oleh BULOG. Program Raskin adalah program adalah sebuah upaya untuk mengurangi beban penyaluran dari rumah tangga miskin sebagai bentuk dukungan dalam meningkatkan ketahanan pangan dengan memberikan perlindungan sosial beras murah dengan jumlah maksimal $15 \mathrm{~kg} /$ rumah tangga miskin/bulan dengan masing-masing harga Rp.1.600,00 per kg (netto) di titik Distribusi [18].

Pengamatan yang penulis lakukan dilapangan dan wawancara dengan salah satu pegawai daerah, ada beberapa faktor masalah dalam melakukan proses Penyaluran Beras Raskin kependudukan di Desa Balonggandu diantaranya sistem pencatatan dan penyimpanan data kependudukan belum maksimal. Setiap pengajuan pada sistem berjalan setiap Kepala Keluarga menyerahkan Fotocopi KTP, Fotocopi KK dan Kartu Indonesia Sehat (KIS). Setelah data dicek dan verifikasi mendapatkan Kartu Penerima Raskin, lalu direkap dengan penggunaan progam aplikasi Microsoft Excel yang menimbulkan keterlambatan proses pendataan. Selain itu proses penyimpanan data yang telah dicetak hanya akan memenuhi lemari berkas dan menyulitkan pencarian data sehingga bisa saja menimbulkan kehilangan. Hal ini juga menyebabkan data bisa diakses siapa saja sehingga memungkinkan terjadinya manipulasi atau perubahan data oleh pihak-pihak yang tidak bertanggung jawab. Melihat lebih luas dampak yang ditimbulkan dari tindakan penyelewengan raskin maka dipandang perlu adanya penanganan serius terhadap masalah ini.Titik kelemahan yang sering dimanfaatkan pelaku penyelewengan yakni pada proses distribusi raskin dari kecamatan ke masyarakat.Penelitian ini bertujuan adalah bagaimana merancang dan membangun sistem informasi distribusi bantuan raskin yang dapat dipergunakan sebagai instrumen pendukung tercapainya administrasi data yang baik dan mendorong transparansi proses distribusi raskin yang berjalan. [25]

Berdasarkan pengamatan dan permasalahan yang telah diuraikan, penulis mencoba membangun sistem yang nantinya memberikan keuntungan, baik dari segi finansial maupun sosial, mempercepat pelayanan kepada masyarakat, memperkenalkan penduduk terhadap teknologi moderen, mengamankan data penduduk dari kecurangan. Dalam hal ini pula secara tidak langsung pemerintah telah menerapkan pelayanan terbaik kepada masyarakat dengan membangun etika sebagai pelayan publik untuk menjauhkan segala bentuk korupsi. Hal ini dilakukan untuk menghindari hal-hal yang telah terjadi pada pendistribusian Raskin sebelumnya didesa Pamekasan Jawa Timur.[4]

\section{METODE PENELITIAN}

Pada penelitian ini penulis menggunakan metode Waterfall dalam mengimplementasikan sistem informasi pengendalian produk berbasis website.

Model air terjun menyediakan pendekatan alur hidup perangkat lunak secara sekuensial atau terurut dimulai dari analisis, desain, pengodean, pengujian, dan tahap pendukung (support ) [16].

Metode ini dibagi menjadi beberapa bagian yaitu: [21]

a. Analisis Kebutuhan Software

proses pengumpulan kebutuhan dilakukan secara intensif untuk menspesifikasikan kebutuhan perangkat lunak agar dapat dipahami perangkat lunak seperti apa yang dibutuhkan oleh user. 
Spesifikasi kebutuhan perangkat lunak pada tahap ini perlu didokumentasikan. Penjelasan gambar dapat dilihat pada gambar 3. 1 (Use Case Diagram Sistem Penyaluran Beras Raskin). Yang terlibat dalam proses penyaluran Beras Raskin adalah Kaur Umum dan Kepala Desa.

\section{b. Desain}

Desain perangkat lunak adalah proses multi langkah yang fokus pada desain pembuatan program perangkat lunak termasuk struktur data, arsitektur perangkat lunak, representasi antar muka, dan prosedur pengodean. Tahap ini mentranslasi kebutuhan perangkat lunak dari tahap analisis kebutuhan ke representasi desain agar dapat diimplementasikan menjadi program pada tahap selanjutnya. Desain perangkat lunak yang dihasilkan pada tahap ini juga perlu didokumentasikan.

\section{c. Pembuatan Code Program}

Desain harus ditranslasikan ke dalam program perangkat lunak. Hasil dari tahap ini adalah program komputer sesuai dengan desain yang telah dibuat pada tahap desain.

\section{d. Pengujian}

Pengujian fokus pada perangkat lunak secara dari segi lojik dan fungsional dan memastikan bahwa semua bagian sudah diuji. Hal ini dilakukan untuk meminimalisir kesalahan (error) dan memastikan keluaran yang dihasilkan sesuai dengan yang diinginkan. Teknik pengujian yang dilakukan dengan menggunakan black box testing.

\section{e. Pendukung (Support) atau pemeliharaan (Maintenance)}

Tidak menutup kemungkinan sebuah perangkat lunak mengalami perubahan ketika sudah dikirimkan ke user.

Perubahan bisa terjadi karena adanya kesalahan yang muncul dan tidak terdeteksi saat pengujian atau perangkat lunak harus beradaptasi dengan lingkungan baru. Tahap pendukung atau pemeliharaan dapat mengulangi proses pengembangan mulai dari analisis spesifikasi untuk perubahan perangkat lunak yang sudah ada, tapi tidak untuk membuat perangkat lunak baru [16].

\subsection{Teknik Pengumpulan Data}

Adapun metode pengumpulan data yang penulis laksanakan yaitu :

\section{a. Observasi}

Istilah observasi berasal dari bahasa latin yang berarti "melihat "memperlihatkan" dan Istilah observasi diarahkan pada kegiatan memperlihatkan secara akurat, mencatat fenomena yang muncul, dan mempertimbangkan hubungan antar aspek dalam fenomena tersebut. Observasi menjadi bagian dalam penelitian berbagai disiplin ilmu, baik ilmu eksakta maupun ilmu-ilmu sosial, observasi dapat berlangsung dalam konteks laboraturium (experimental) maupun konteks alamiah. Observasi dilakukan pada Desa Balonggandu Jatisari Karawang.

\section{b. Study Literatur}

Study literatur (kajian pustaka) merupakan penelusuran literatur yang bersumber dari buku, media, pakar ataupun dari hasil penelitian orang lain yang bertujuan untuk menyusun dasar teori yang kita gunakan dalam melakukan penelitian. Salah satu sumber acuan dimana peneliti dapat menggunakannya sebagai petunjuk informasi dalam menelusuri bahan bacaan adalah dengan menggunakan buku referensi. Referensi berasal dari bahasa inggris reference 
yang berarti "menunjuk pada". Buku-buku referensi ini dapat berisi uraian singkat atau penunjukkan nama dari bacaan tertentu. Bahan dari buku referensi tidaklah untuk dibaca dari halaman pertama sampai tamat, hanya bagian yang penting dan yang diinginkan saja.

c. Wawancara

Wawancara (interview) merupakan percakapan antara dua orang atau lebih dan berlangsung antara narasumber dan pewawancara. Tujuan dari wawancara adalah untuk mendapatkan informasi dimana pewawancara melontarkan pertanyaan-pertanyaan untuk dijawab oleh orang yang diwawancarai. Wawancara dilakukan kepada salah satu pegawai Kecamatan Bpk Mulyadi (Kaur Umum). Pertanyaaan seputar Raskin yaitu, sudah berapa lama penerimaan Raskin dan bagaimana pelayanan Desa terhadap penyaluran beras Raskin. Wawancara juga dilakukan kepada penerima Raskin Ibu Resih dan Bapak Ade Hasan.

\subsubsection{Analisis Kebutuhan}

A. Kebutuhan Pengguna

Dalam perancangan sistem informasi penyaluran beras ini terdapat 2 (dua) pengguna yang dapat saling berinteraksi dalam lingkungan sistem, yaitu: KAUR UMUM (Admin), dan Kepala Desa. Kedua pengguna tersebut memiliki karakteristik interaksi dengan sistem yang berbeda-beda dan memiliki kebutuhan informasi yang berbeda-beda, seperti berikut :

\section{A1. Skenario Kebutuhan KAUR UMUM (Admin)}
a) Admin melakukan Login
b) Admin dapat mengelola data warga
c) Admin dapat mengelola data beras raskin.
d) Admin dapat mengelola data penerima raskin.
e) Admin dapat mencetak Laporan

\section{A2. Skenario Kebutuhan Kepala Desa}
a) Kepala Desa melakukan Login
b) Kepala Desa dapat melihat data warga.
c) Kepala Desa dapat melihat data beras.
d) Kepala desa dapat melihat data penerima raskin
e) Kepala Desa dapat melihat data laporan.

B. Kebutuhan Sistem

Dalam merancang sistem informasi penyaluran beras Raskin ini, informasi yang diperlukan adalah output yang dihasilkan dari aplikasi tersebut. Untuk itu dibutuhkan kebutuhan sistem yang terdiri dari:

1) Admin harus melakukan login untuk dapat mengakses menu utama dengan memasukan username dan password.

2) Sistem akan menampilkan pesan login berhasil atau login gagal jika salah.

3) Admin harus melakukan logout setelah selesai dengan memasukan username dan password.

4) Sistem akan menampilkan pesan logout berhasil atau logout gagal jika salah.

5) Sistem akan menampilkan menu utama.

6) Sistem akan menampilkan notifikasi/pesan apabila data tersimpan, diubah, dihapus, ditambah, dicetak.

7) Sistem akan memproses dan menampilkan data pencarian.

8) Sistem akan melakukan perintah cetak. 


\subsubsection{Rancangan Diagram Use Case}

Pada Use Case Sistem Penyaluran Beras Raskin KAUR UMUM (Admin) dan Kepala Desa melakukan login untuk menampilkan data penerima Raskin

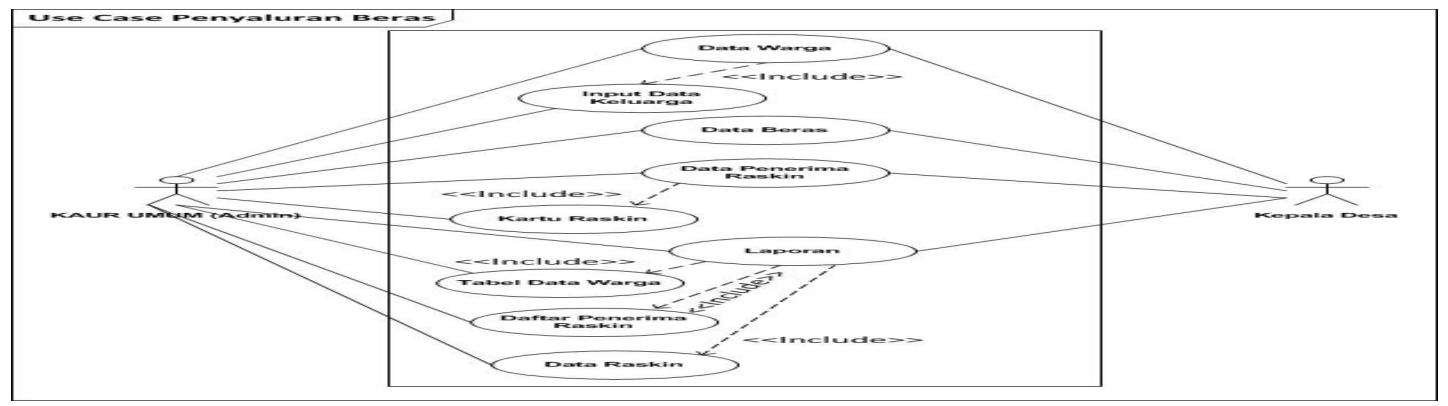

Gambar 3.1. Use Case Diagram Sistem Penyaluran Beras Raskin

A1. a) Admin Melakukan Login

Pada Use Case Admin (Kaur Umum) Melakukan Login fungsinya Admin melakukan Login

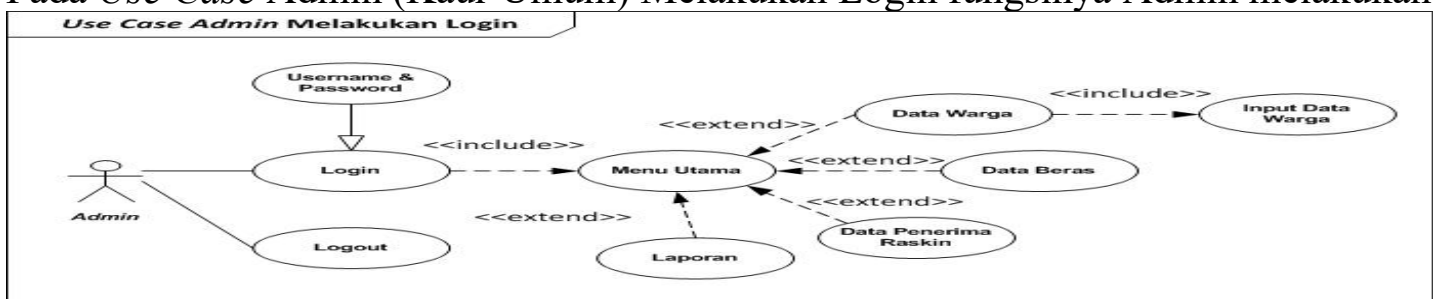

\section{Gambar 3.2. Use Case Admin Melakukan Login}

\section{A1.b) Admin Mengelola Data Warga}

Pada Use Case Admin (Kaur Umum) mengelola data warga, fungsinya Admin melakukan mengelola data warga.

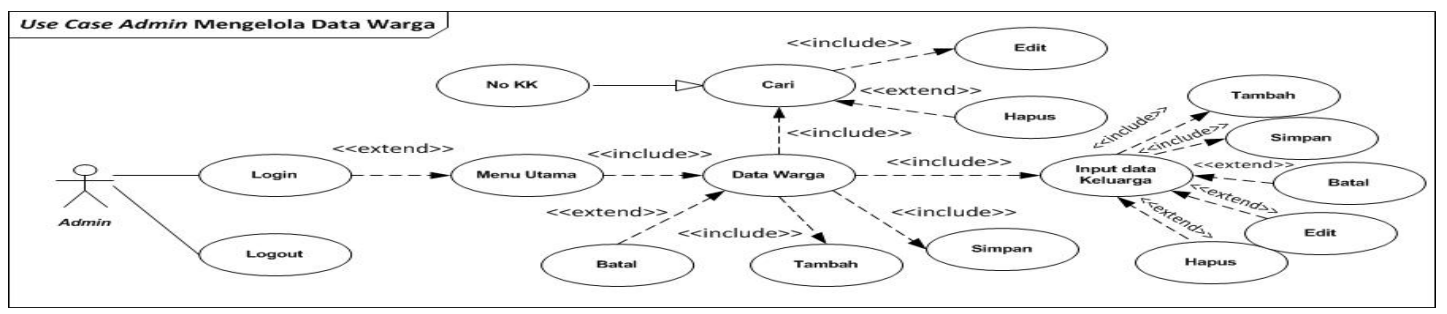

Gambar 3.3. Use Case Admin Mengelola Data Warga 


\section{A1.c) Admin Mengelola Data Raskin}

Pada Use Case Admin mengelola data Raskin, fungsinya Admin melakukan mengelola data stok Raskin.

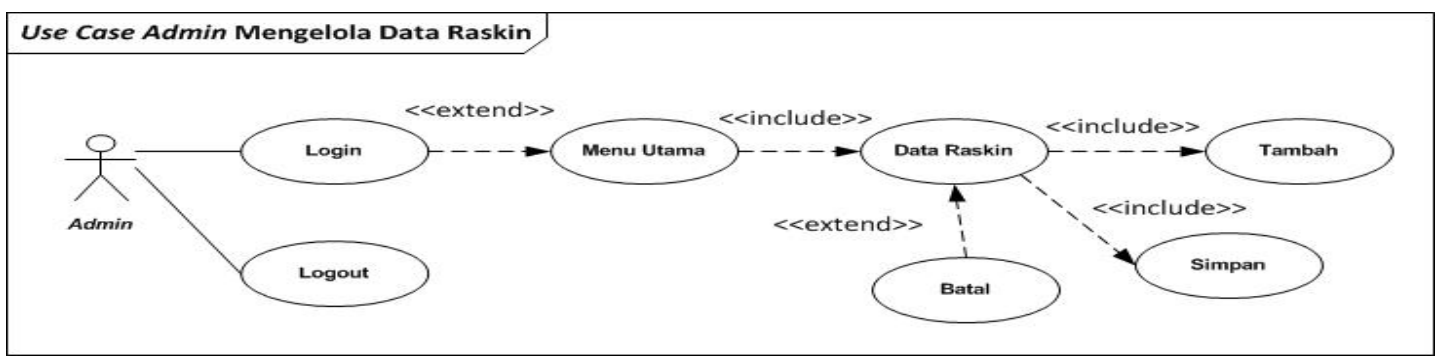

\section{Gambar 3.4. Use Case Admin Mengelola Data Raskin}

\section{A1.d) Admin Mengelola Data Penerima Raskin}

Pada Use Case Admin mengelola data penerima Raskin, fungsinya Admin melakukan mengelola data Penerima Raskin dan menambah data penerima Raskin.

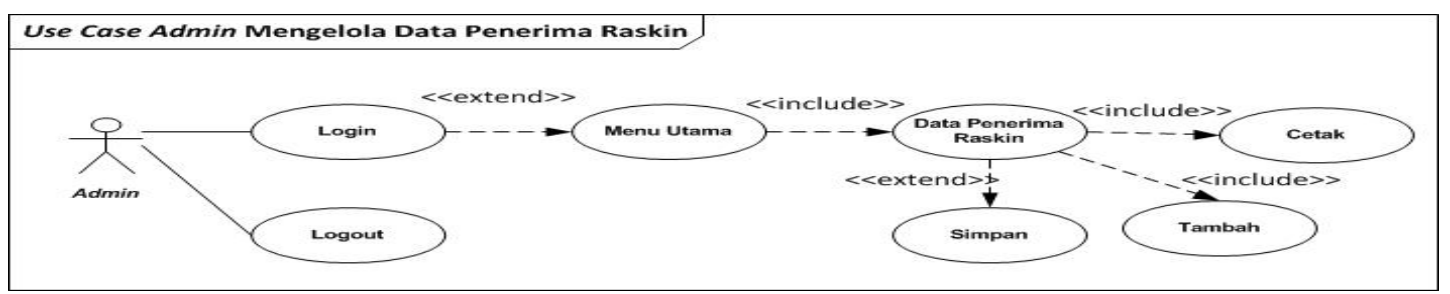

Gambar 3.5. Use Case Admin Mengelola Data Penerima Raskin

\section{A1.e) Admin Mencetak Laporan}

Pada Use Case Admin mencetak laporan, fungsinya Admin mencetak data Penerima Raskin.

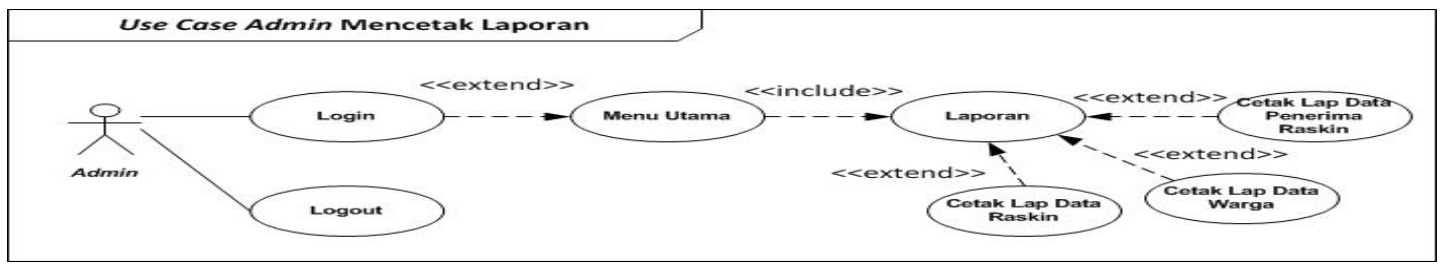

Gambar 3.6. Use Case Admin Mencetak Laporan

\section{A2. a) Kepala Desa Melakukan Login}

Kepala Desa melakukan login dengan memasukkan Username dan Password, Sistem akan melakukan validasi data pada database dan menampilkan keterangan "Login Berhasil"

Sistem akan menampilkan menu utama. 


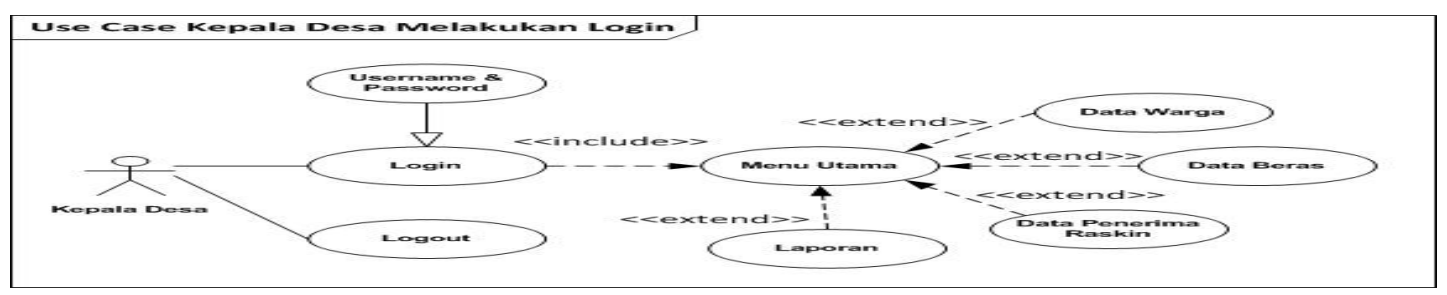

Gambar 3.7. Use Case Kepala Desa Melakukan Login

\section{A2. b) Kepala Desa Melihat DataWarga}

Kepala Desa melakukan login dengan memasukkan Username dan Password, Sistem akan melakukan validasi data pada database dan menampilkan keterangan "Login Berhasil", Sistem akan menampilkan menu utama, Pilih "Data Warga" untuk membuka menu Data Warga.

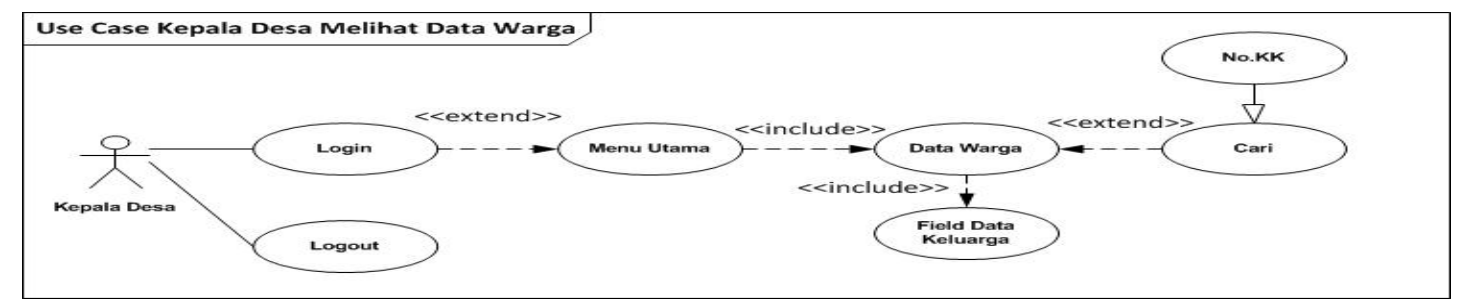

Gambar 3.8. Use Case Kepala Desa Melihat Data Warga

\section{A2. c) Kepala Desa Melihat Data Raskin}

Kepala Desa melakukan login dengan memasukkan Username dan Password, Sistem akan melakukan validasi data pada database dan menampilkan keterangan "Login Berhasil", Sistem akan menampilkan menu utama, Pilih "Data Raskin" untuk melihat stok Data Raskin

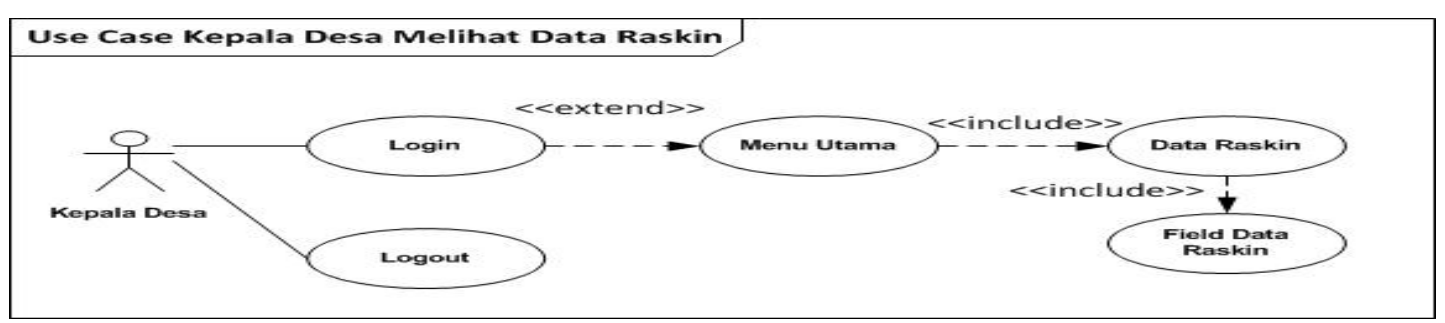

Gambar 3.9 Use Case Kepala Desa Melihat Data Raskin 


\section{A2.d) Kepala Desa Melihat Data Penerima Raskin}

Kepala Desa melakukan login dengan memasukkan Username dan Password., Sistem akan melakukan validasi data pada database dan menampilkan keterangan "Login Berhasil", Sistem akan menampilkan menu utama, Pilih "Data Penerima Raskin" untuk melihat warga penerima beras Raskin.

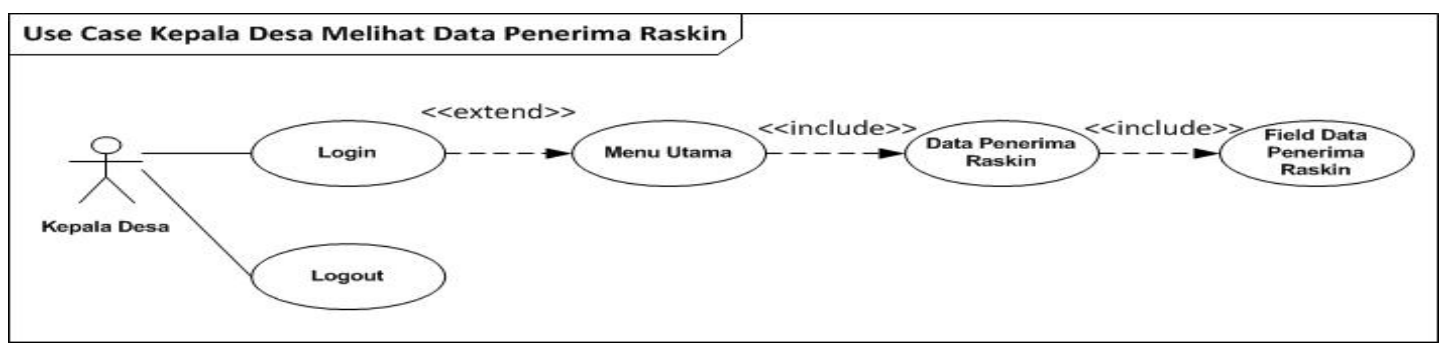

Gambar 3.10.

\section{Use Case Kepala Desa Melihat Data Penerima Raskin}

\section{A2.e) Kepala Desa Melihat Laporan}

Kepala Desa melakukan login dengan memasukkan Username dan Password, Sistem akan melakukan validasi data pada database dan menampilkan keterangan "Login Berhasil", Sistem akan menampilkan menu utama, Pilih "Laporan" untuk melihat Laporan data, Sistem akan menampilkan menu Laporan

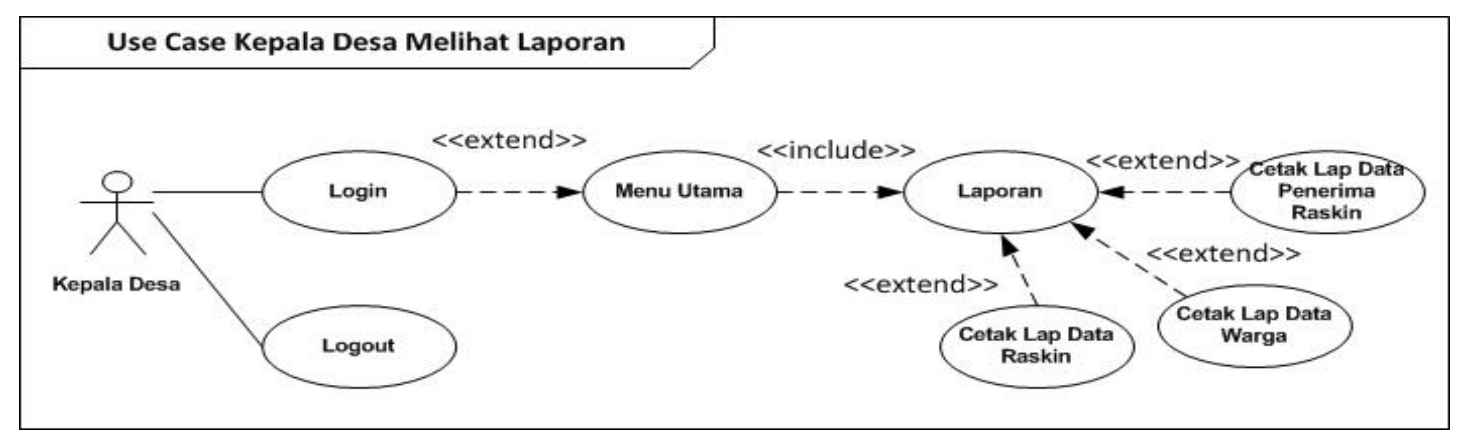

Gambar 3.11. Use Case Kepala Desa Melihat Laporan 
3.1.3. Rancangan Diagram Aktivitas (Penjelasan pada masing-masing Rancangan Diagram Aktivitas diagram sama dengan penjelasan pada masing-masing Use Case Diagaram).

\section{Admin Mengelola Data Warga}

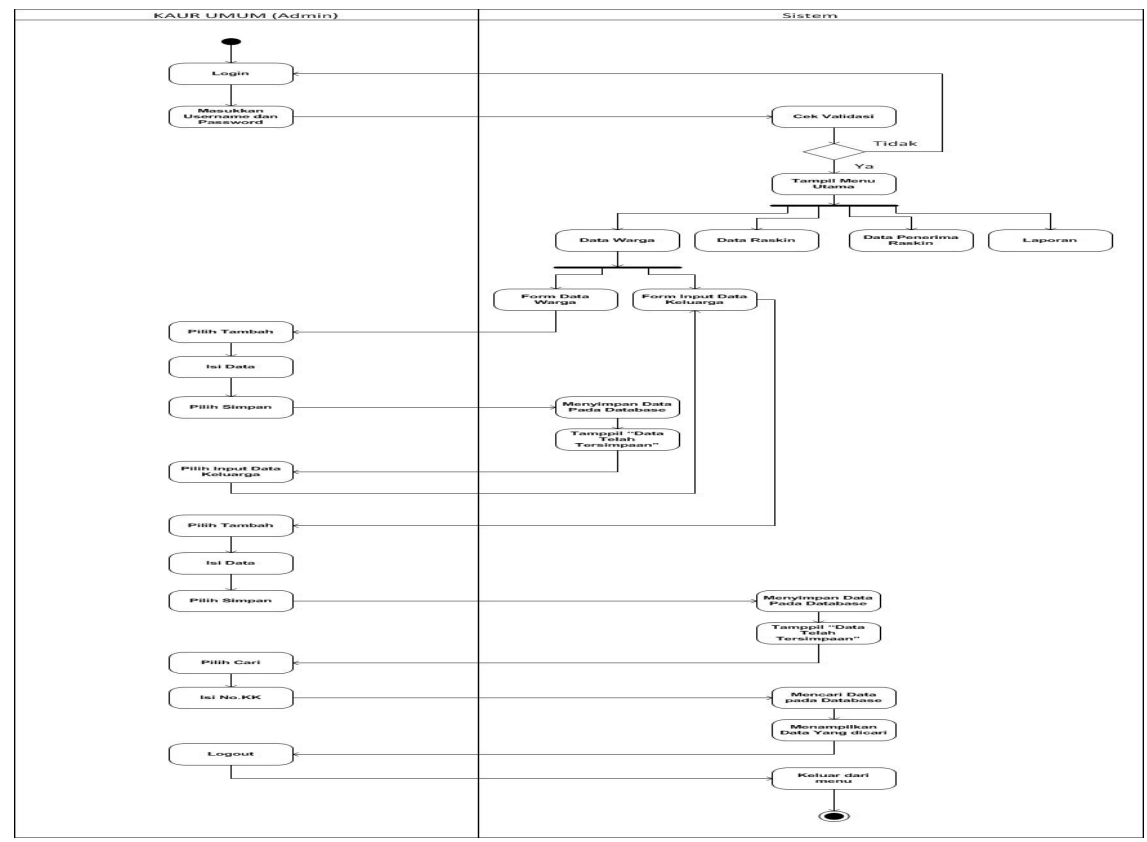

Gambar 3.12. Rancangan Diagram Aktivitas $A d m i n$ Mengelola Data Warga

\section{Admin Mengelola Data Raskin}

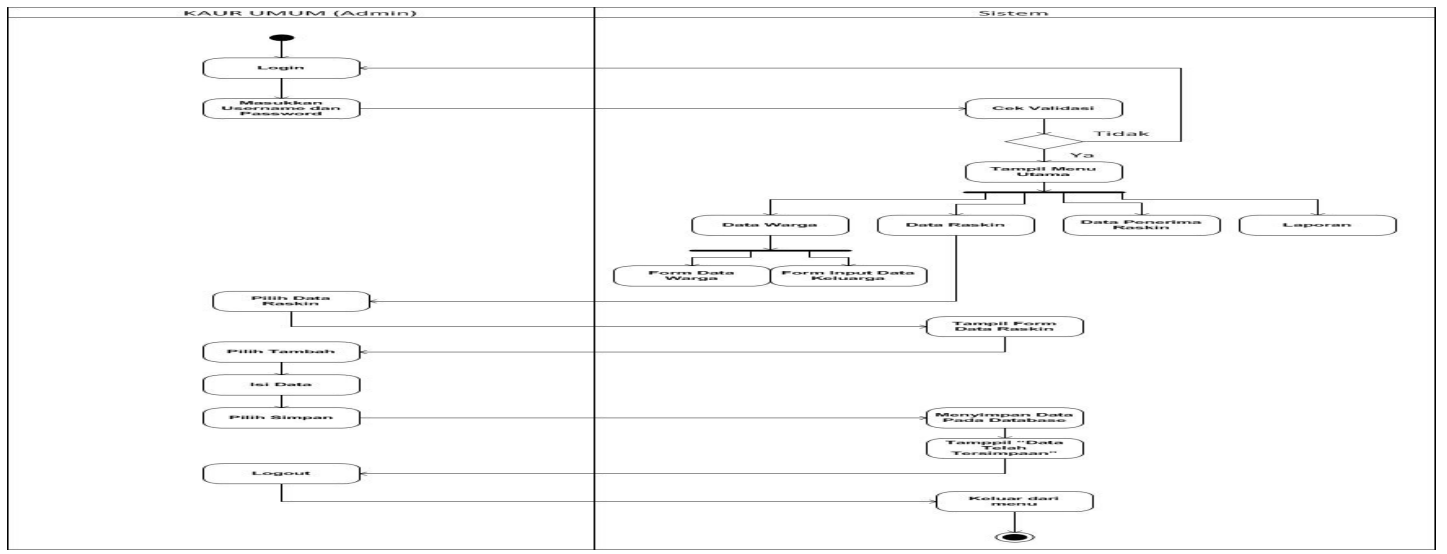

Gambar 3.13. Rancangan Diagram Aktivitas Admin Mengelola Data Raskin 
3. Admin Mengelola Data Penerima Beras Raskin

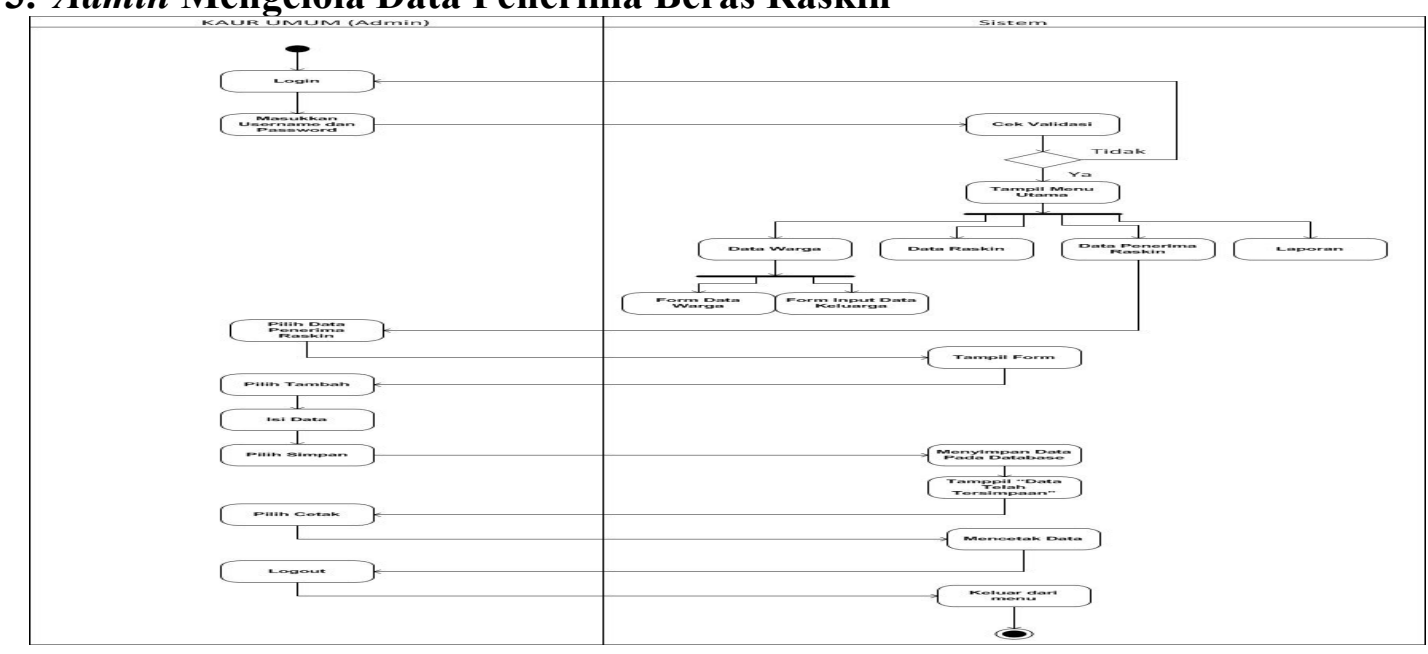

Gambar 3.14. Rancangan Diagram Aktivitas Admin Mengelola Data Penerima Raskin

4. Admin Mencetak Laporan

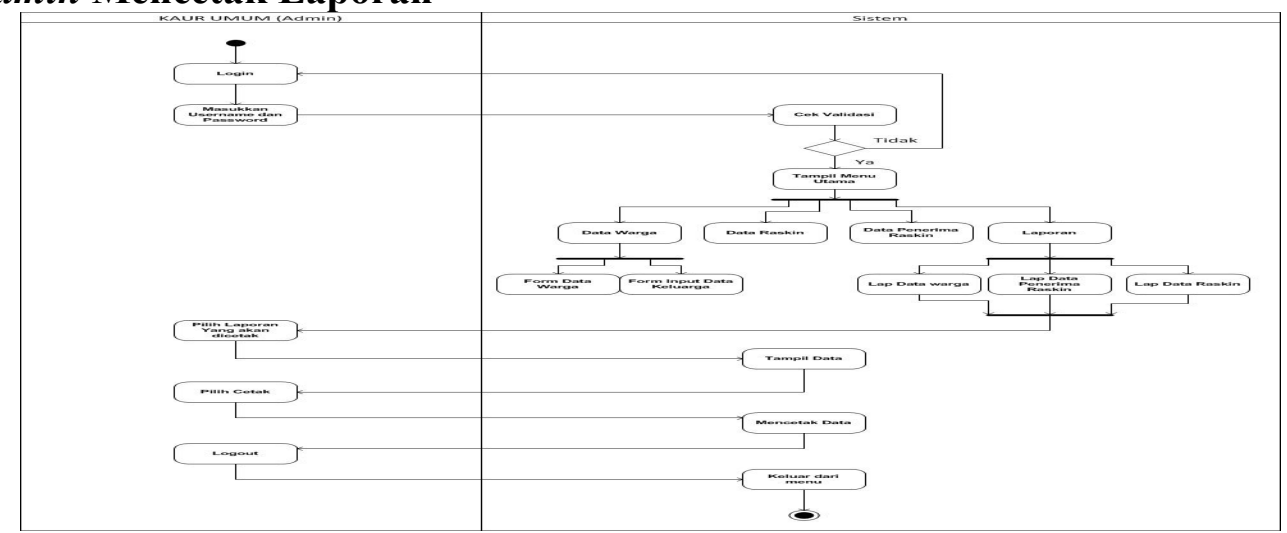

Gambar 3.15. Rancangan Diagram Aktivitas Admin Mencetak Laporan

5. Kepala Desa Melihat Data Warga

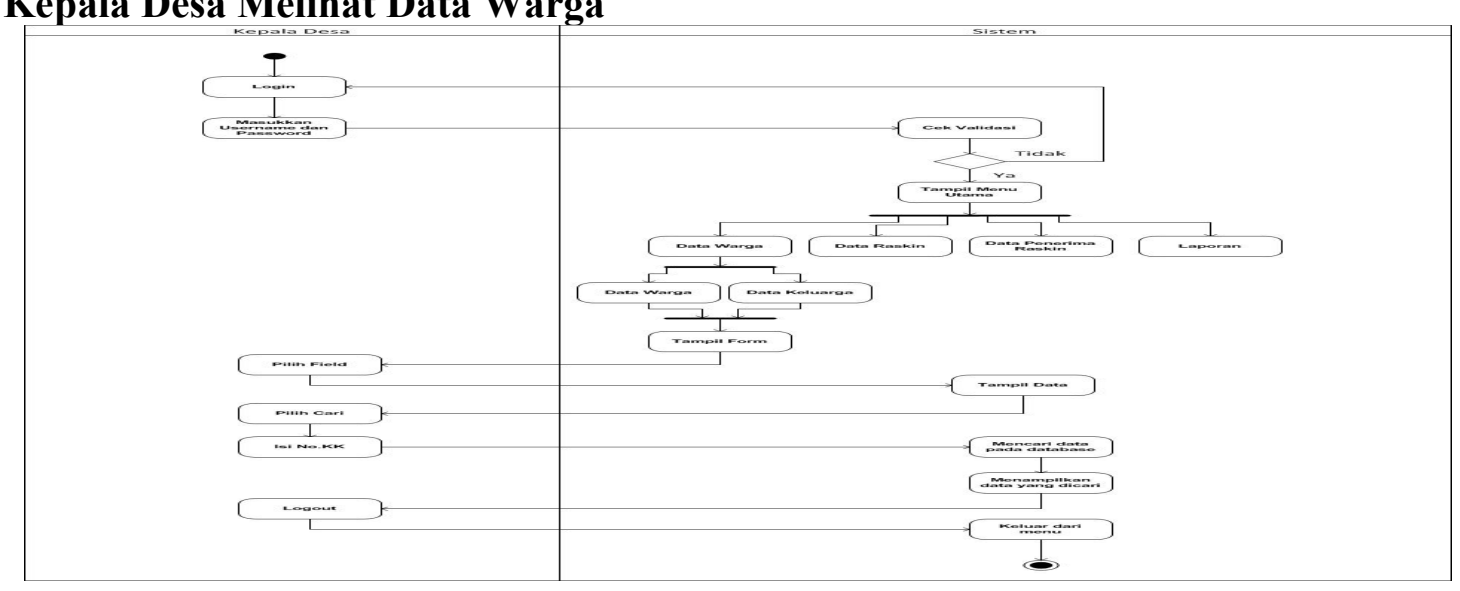

Gambar 3.16. Rancangan Diagram Aktivitas Kepala Desa Melihat Data Warga 
6. Kepala Desa Melihat Data Raskin

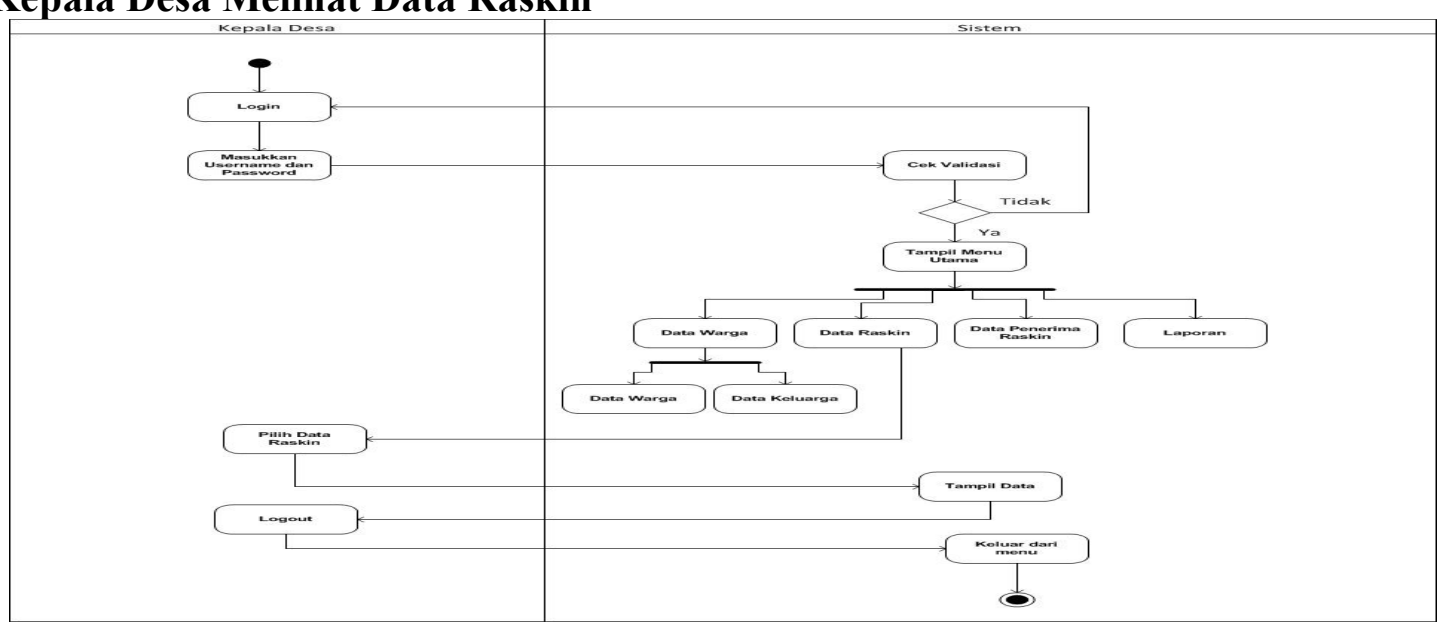

Gambar 3.17. Rancangan Diagram Aktivitas Kepala Desa Melihat Data Raskin

7. Kepala Desa Melihat Data Penerima Raskin

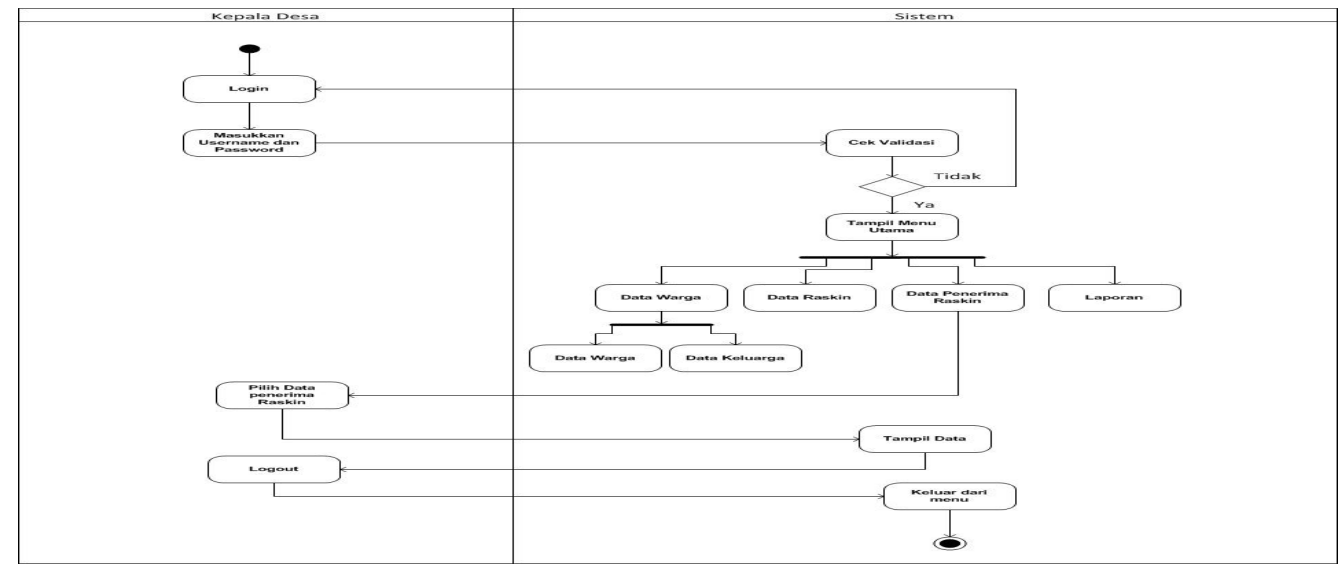

Gambar 3.18.

Rancangan Diagram Aktivitas Kepala Desa Melihat Data Penerima Raskin

8. Kepala Desa Melihat Laporan

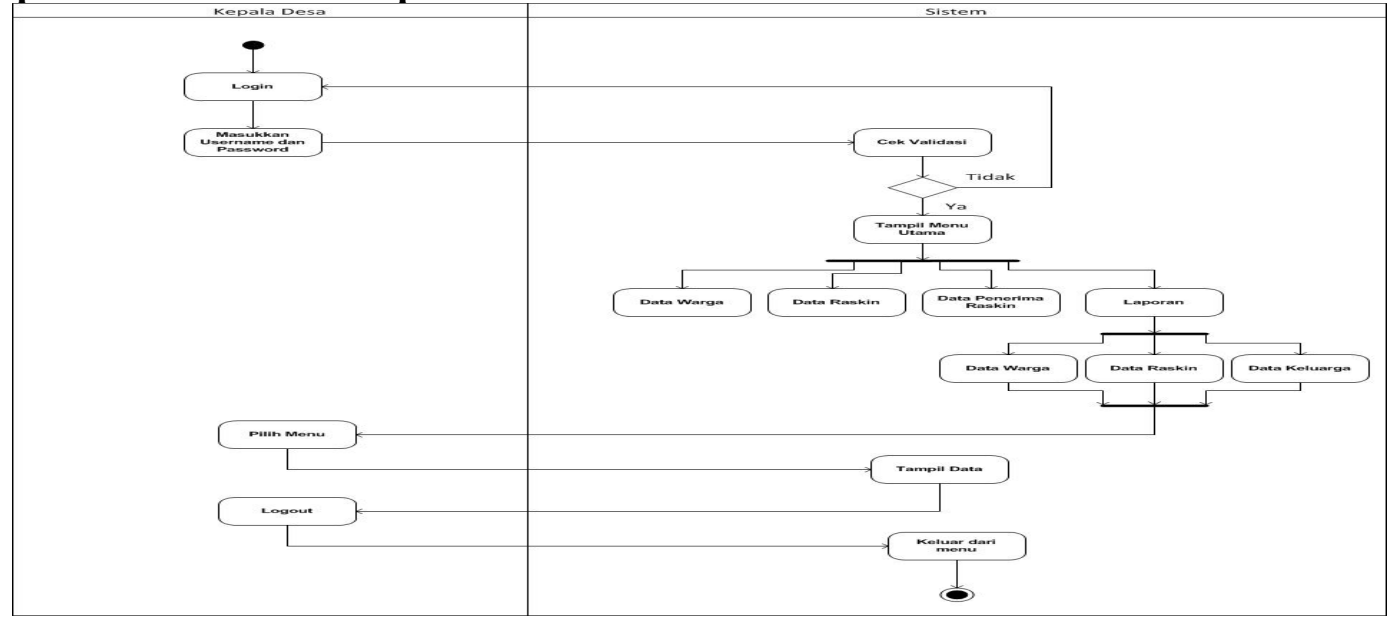

Gambar 3.19. Rancangan Diagram Aktivitas Kepala Desa Melihat Laporan 


\subsubsection{Rancangan Prototype}

\section{Rancangan Form Login Admin}

Fungsinya untuk membatasi akses login Admin yang disediakan pada layanan sistem informasi tersebut.

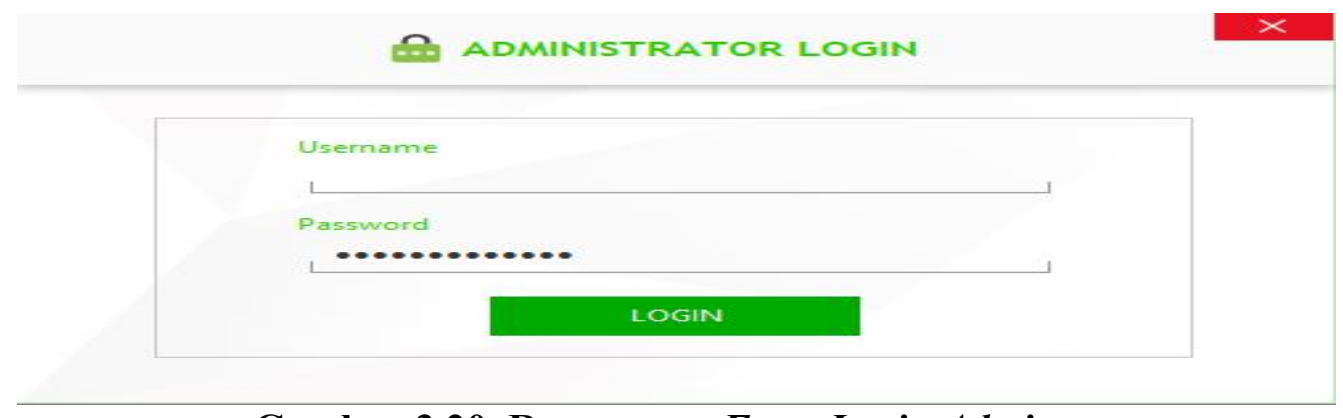

\section{Gambar 3.20. Rancangan Form Login Admin}

\section{Rancangan Form Menu Utama Admin}

Setelah melakukan login terhadap menu input data warga, Input Data Raskin, Penerima Raskin, dan Mencetak Laporan.

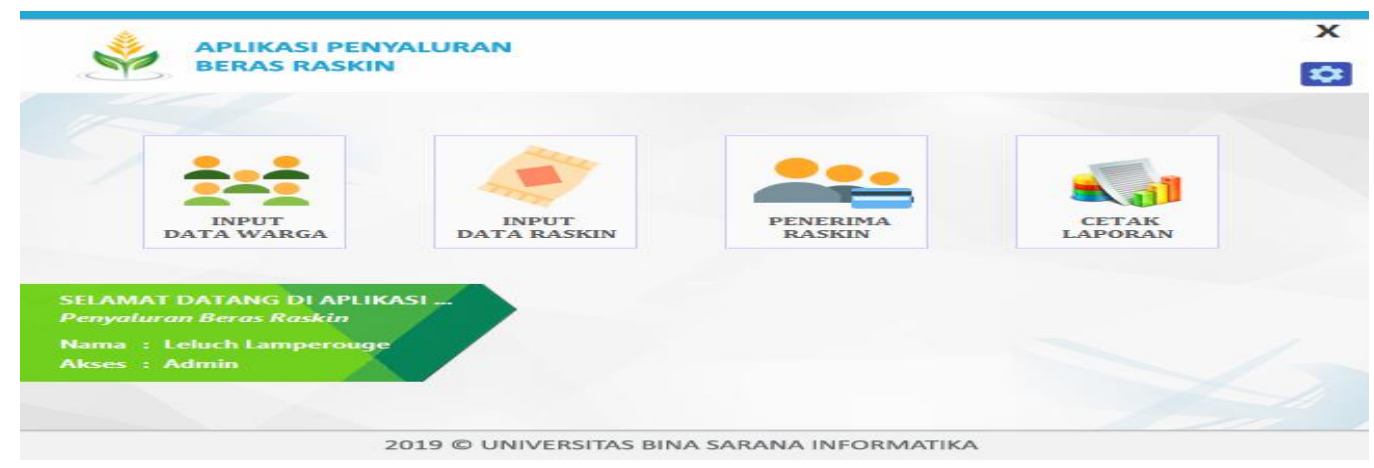

Gambar 3.21. Rancangan Form Menu Utama Admin

\section{Rancangan Form Menu Data Warga Admin}

Pada saat masuk kemenu Input Data warga, akan tampil form pengisian data warga

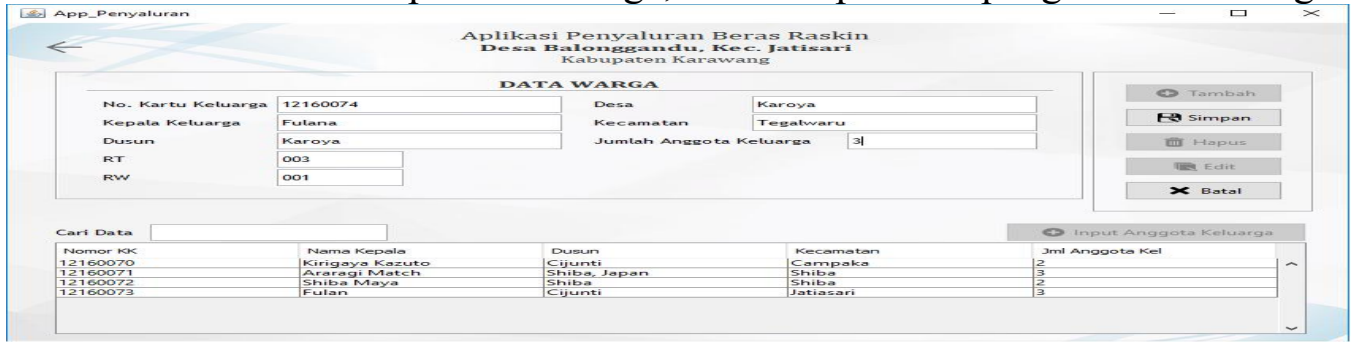

Gambar 3.22.

Rancangan Form Menu Data Warga Admin

\section{Rancangan Form Input Data Keluarga Admin}

Pada saat masuk kemenu Input Data warga, akan tampil form pengisian data warga, lalu klik simpan setelah diinput 


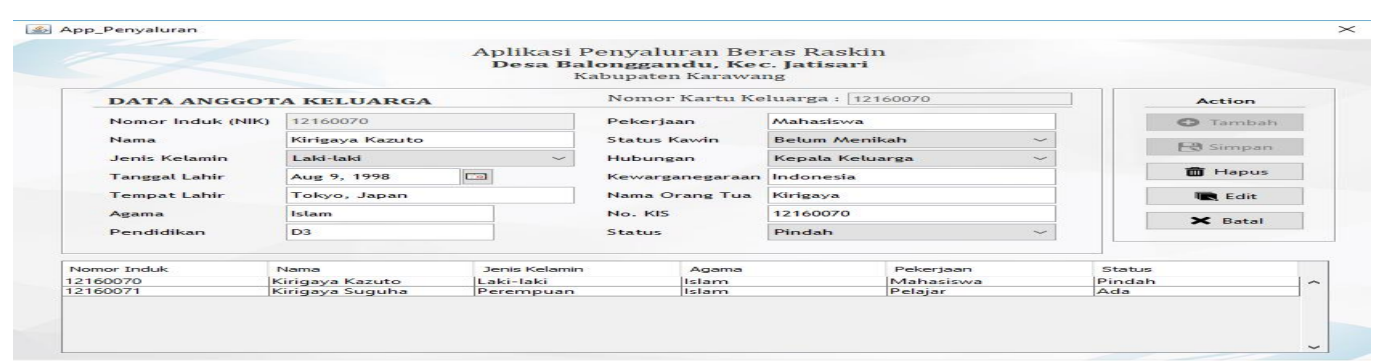

Gambar 3.23.

Rancangan Form Input Data Keluarga Admin

\section{Rancangan Form Menu Data Raskin Admin}

Pada saat memilih menu Penerima Raskin, akan tampilan menu data beras raskin yang akan diberikan kepada penerima Raskin

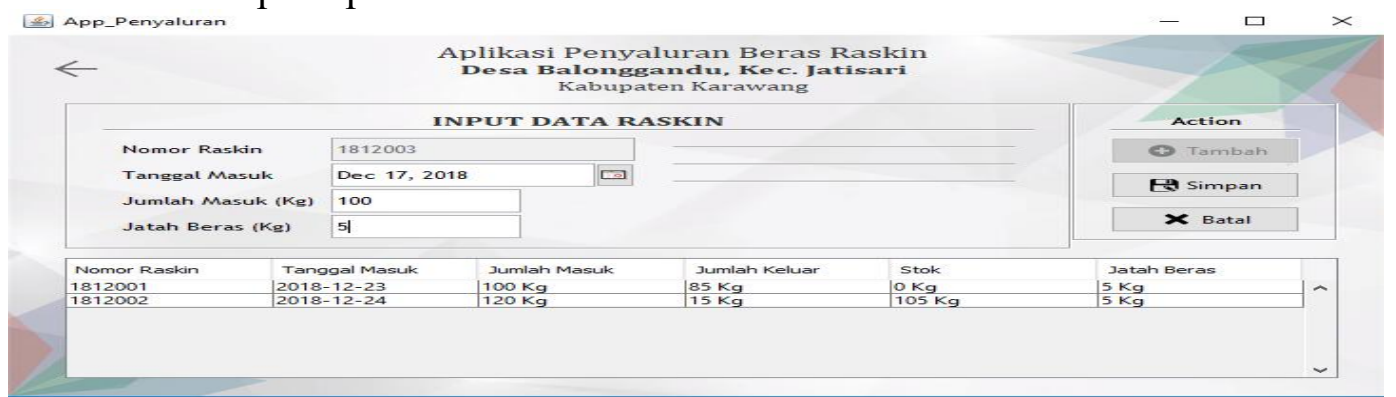

Gambar 3.24.

Rancangan Form Menu Data Raskin Admin

\section{Rancangan Form Menu Penerima Raskin Admin}

Lalu menu tampilan penerima Raskin

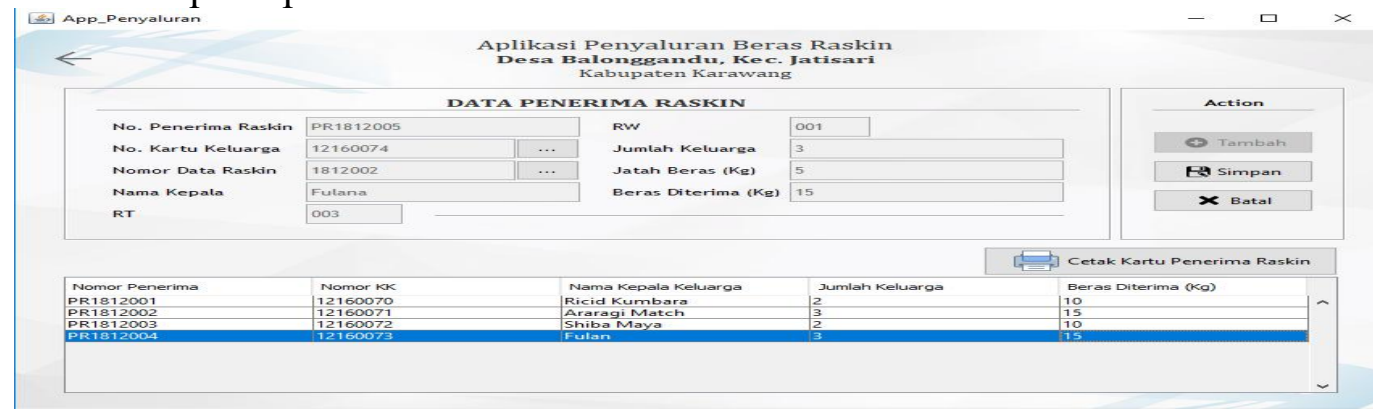

Gambar 3.25.

Rancangan Form Menu Penerima Raskin Admin

\section{Rancangan Form Menu Laporan Admin}

Dan setelah dipilih menu Laporan akan tampil Cetak Penerima Data Raskin, Cetak Laporan data Warga dan Cetak Laporan Data Raskin

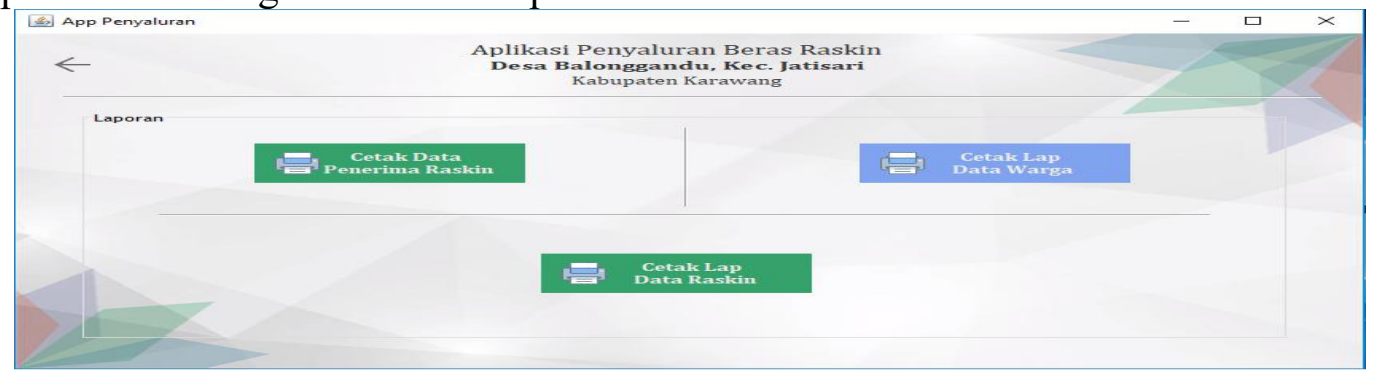

Gambar 3.26. Rancangan Form Menu Laporan Admin 


\section{Rancangan Form Login Kepala Desa}

Fungsinya untuk membatasi akses login Kepala Desa yang disediakan pada layanan sistem informasi tersebut.

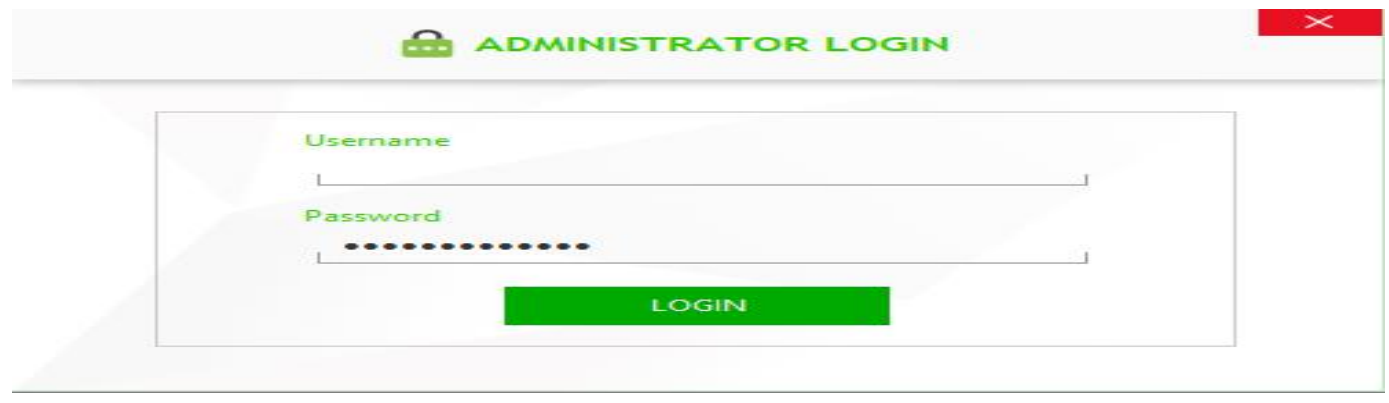

Gambar 3.27.

Rancangan Form Login Kepala Desa

\section{Rancangan Form Menu Utama Kepala Desa}

Setelah melakukan login terhadap menu melihat data warga, Data Raskin, Penerima Raskin, dan Mencetak Laporan.

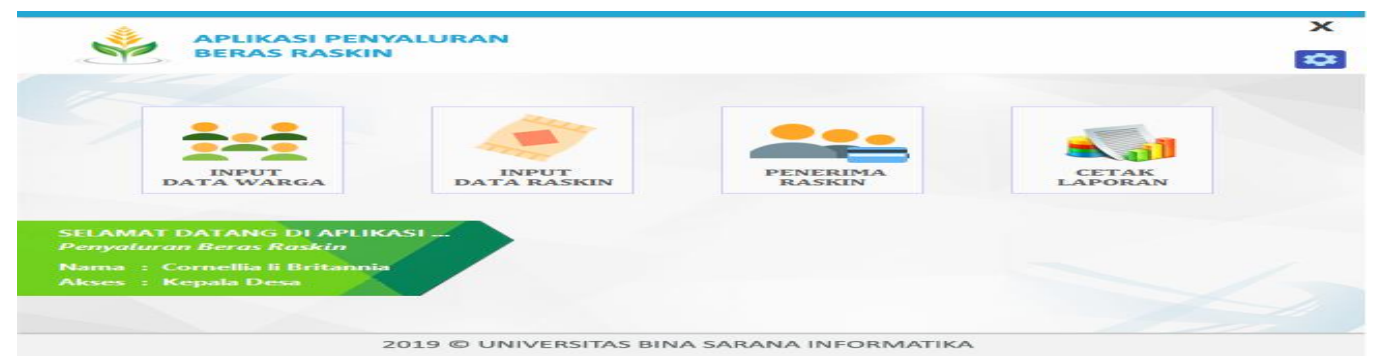

Gambar 3.28.

Rancangan Form Menu Utama Kepala Desa

10. Rancangan Form Menu Data Warga Kepala Desa

Pada saat masuk kemenu melihat Data warga, akan tampil form pengisian data warga

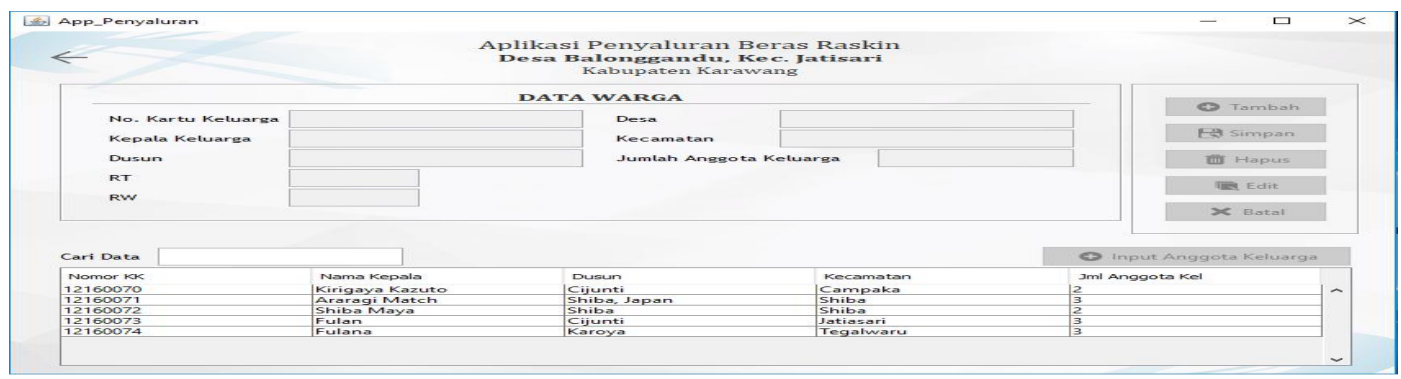

Gambar 3.29.

Rancangan Form Menu Data Warga Kepala Desa

11. Rancangan Form Data Keluarga Kepala Desa

Pada saat masuk kemenu Data warga, Kepala Desa dapat melihat Data-data yang sudah masuk. 


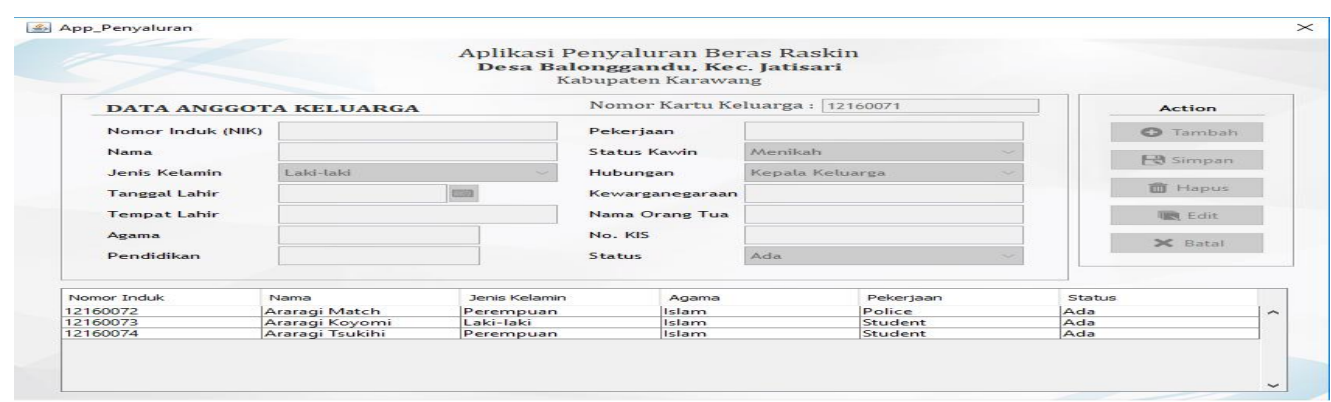

Gambar 3.30.

\section{Rancangan Form Data Keluarga Kepala Desa}

12. Rancangan Form Menu Data Raskin Kepala Desa

Pada saat memilih menu Penerima Raskin, akan tampilan menu data beras raskin yang akan diberikan kepada penerima Raskin

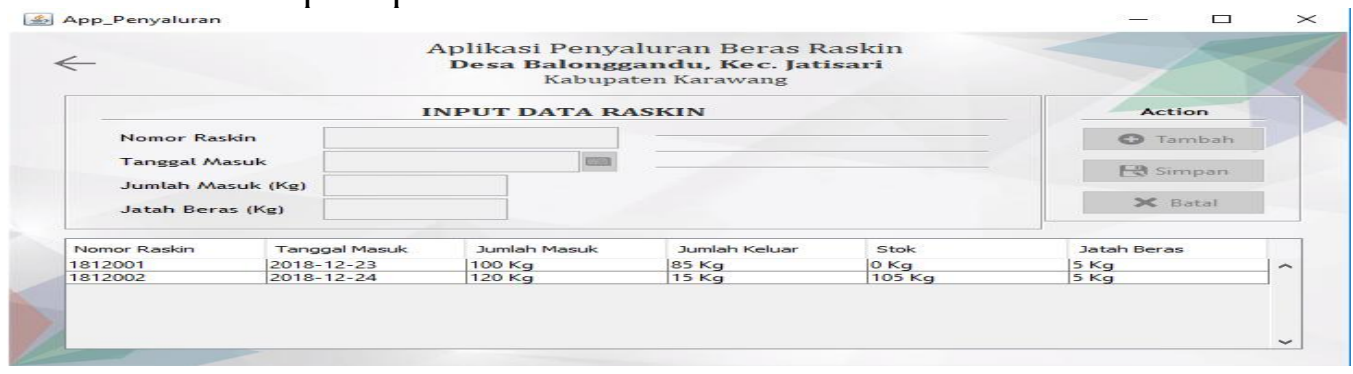

Gambar 3.31.

Rancangan Form Menu Data Raskin Kepala Desa

13. Rancangan Form Menu Penerima Raskin Kepala Desa

Lalu menu tampilan penerima Raskin

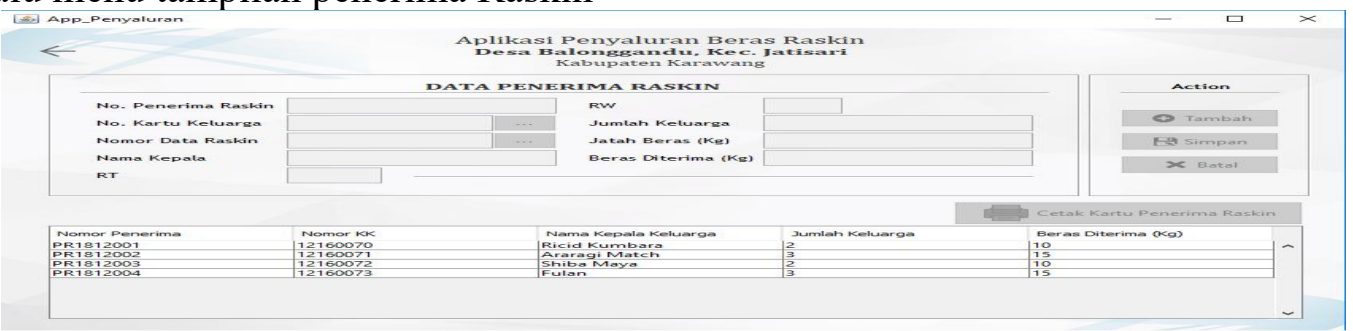

Gambar 3.32.

Rancangan Form Menu Penerima Raskin Kepala Desa

14. Rancangan Form Menu Laporan Kepala Desa

Dan setelah dipilih menu Laporan akan tampil Cetak Penerima Data Raskin, Cetak Laporan data Warga dan Cetak Laporan Data Raskin

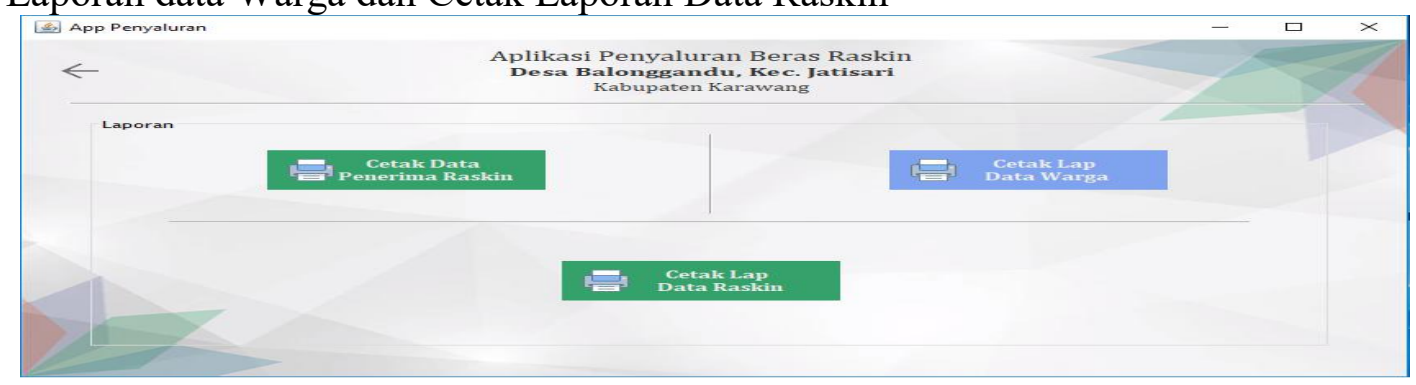

Gambar IV.33.

Rancangan Form Menu Laporan Kepala Desa 


\section{KESIMPULAN}

Berdasarkan yang telah dilakukan selama membangun dan mengimplementasikan, dapat ditarik beberapa kesimpulan yaitu:

1. Sistem informasi penyaluran beras Raskin yang sedang berjalan masih bersifat konvensional dan membutuhkan waktu yang lama serta sering terjadi kesalahan dalam pencatatan data warga serta masih minimnya pemahaman pegawai mengenai bagaimana pengelolaan data yang efektif dan efisiensi sehingga didalam pelaksanaannya terdapat ketidak sesuaian dalam pengelolaan data warga dengan data dari pemerintah. Masih ada beberapa warga yang tidak terdata penerima Raskin, meskipun telah menyearahkan datadata untuk memperoleh Raskin.

2. Sistem informasi penyaluran beras Raskin yang diusulkan adalah dengan menggunakan sistem informasi secara komputerisasi maka proses penginputan dan pencarian data tersimpan dengan aman dan terstruktur serta tidak terjadi lagi kesalahan dalam pencarian data. Dan stok beras dapat dikontrol sehingga meminimalisir kecurangan dalam sistem penyaluran beras Raskin yang ada pada Desa Balonggandu. Hal ini bisa dicek melalui menu Penerima Raskin, datanya sesuai dengan KTP dan Kartu Keluarga yang didaftarkan.

3. Sudah adanya data sistem informasi penyaluran beras Raskin lebih baik sehingga dapat meningkatkan produktifitas kerja khususnya dari segi proses penyaluran beras Raskin, sehingga data yang dibutuhkan menjadi lebih cepat dan akurat.

\section{DAFTAR PUSTAKA}

[1] Anggraeni, Yuaneti Elisabet dan Rita Irviani. 2017. Pengantar Sistem Informasi. Yogyakarta

[2] Febtiasari, A. (2017). Implementasi Kebijakan Manajemen Hibah Pada Badan Pengelolaan Keuangan Dan Aset Daerah Provinsi Sulawesi Tengah. Diambil dari https://jurnal. Untad.ac.id (Diakses Tgl: 20 Mei 2020).

[3] Darmawan, Deni dan Kunkun Nur Fauzi. 2013. Sistem Informasi Manajemen. Bandung: PT. Remaja Rosdakarya.

[4] Diakses 27 Mei 2020 dari https://regional.kompas.com/read/2017/06/05/16541681/korupsi.raskin.dua.kepala.desa. dipecat

[5] Dini Silvi Purnia, A. R. (2019). Penerapan Metode Waterfall dalam Perancangan Sistem Informasi Aplikasi Bantuan Sosial Berbasis Android. Jakarta: Fakultas Teknologi Universitas Muhamadiyah Jakarta, dambil dari https://jurnal.umj.ac.id (Diakses Tgl: 20 Mei 2020)

[6] Hartono, Bambang. 2013. Sistem Informasi Manajemen Berbasis Komputer. Jakarta: Rineka Cipta

[7] Hendini, Ade. 2016. Permodelan UML Sistem Informasi Monitoring Penjualan dan Stok Barang (Studi Kasus: Distro ZheZha Pontianak). Diambil dari: http://ejournal.bsi.ac.id (Diakses tgl 15 November 2018).

[8] Hutahaean, Jeperson. 2014. Konsep Sistem Informasi. Yogyakarta: Deepublish. 
[9] Isnandi, Bambang Eka Purnama dan Siska Ariani, 2015. Pembangunan Aplikasi Pembelian dan Penjualan Barang Pada Toko Ritzca Elektronik Pulung. Diambil dari: http://download.portalgaruda.org (23 November 2018).

[10] Kadir, Abdul. 2014. Pengenalan Sistem Informasi.Yogyakarta: CV.Andi Offset.

[11] Khosim, Noer. 2017. Model-Model Pembelajaran.. Jakarta: Suryamedia Publishing.

[12] Kusuma, M. S. (2015). Analisis Efektivitas Distribusi Beras Miskin (Raskin) di Kota Medan, diambil dari https://www.neliti.com (Diakses Tgl: 20 Mei 2020)

[13] Ladjamudin. 2013. Rekayasa Perangkat Lunak. Yogyakarta:Graha Ilmu.

[14] Latumakulita, Luther.A.2013. Sistem Pendukung Keputusan Distribusi Beras Miskin (raskin) Menggunakan Logika Samar. Diambil dari: http://eprints.dinus.ac.id(Diakses Tgl:04 Desember 2018).

[15] Makawimban, Gerry, Sjendry, S. R. Loindon, 2016, Analisis Distribusi Beras Miskin (Raskin) Di Perum Bulog Drive Sulut Dan Gorontalo (Studi Pada Kecamatan Sario Kelurahan Titiwungen Selatan), diambil dari https://ejournal.unsrat.ac.id

[16] Mulyani,Sri. 2017. Metode Analisis dan Perancangan Sistem. Bandung: Abdi Sistematika.

[17] Nugroho, Bunafit. 2014. Membuat Sistem Informasi Akademik Sekolah dengan PHPMySQL \& Dreamweaver. Yogyakarta:Gava Media.

[18] Ovianti Vivi, Haji Wachyu Hari, 2019, Rancang Bangun Aplikasi Distribusi Minyak Sawit Pt . Steelindo Wahana Perkasa Cabang Belitung Timur, Diambil dari : https://jurnal.dcc.ac.id (Diakses Tgl: 20 Mei 2020).

[19] Punjul, Sunu Jaluanto. 2016. Sistem Informasi Manajemen. Yogyakarta:Deepublish.

[20] Pratiwi, Anna Indah. 2013. Sistem Informasi Penyaluran Beras Raskin Pada Perum Bulog Divre Jateng. Diambil dari: https://ejournal.unsrat.ac.id (Diakses Tgl: 04 Desember 2018).

[21] Rosa,A.S dan M. Shalahuddin. 2016. Rekayasa Perangkat Lunak Terstruktur dan Berorientasi Objek. Bandung: Informatika Bandung.

[22] Saputra Noverdi, 2016, Pendistribusian Beras Miskin (Raskin) Di Kelurahan Delima Kecamatan Tampan Kota Pekanbaru Tahun 2016, diambil dari https://www.neliti.com (Diakses Tgl: 20 Mei 2020)

[23] Supriadi, Deddy. dan Leli Fitriani. 2018. Sistem Informasi Zakat Berbasis Web. Diambil dari: http://ejournal.bsi.ac.id (Diakses tgl 04 Desember 2018).

[24] Suryadi, Lis. 2013. Analisis dan Perancangan Sistem Infomasi Pendistribusian GAS LPG Bersubsidi dengan Metodologi Object Oriented Studi Kasus PT.XYZ. Diambil dari: https://media.neliti.com (Diakses tgl 04 Desember 2018).

[25] Tone, Kamaruddin. 2016. Rancang Bangun Sistem Informasi Distribusi Sosial Beras Miskin (Studi Kasus Kecamatan Binamu Kabupaten Jeneponto). Diambil dari: http://journal.uin-alauddin.ac.id (Diakses tgl 04 Desember 2018).

[26] Yanto, Robi. 2016. Manajemen Basis Data Menggunakan MySQL. Yogyakarta:Deepublish. 